\title{
When Foucault Met Xenophon: How the Ecosystem of the Ancient Greek Moderation Establishes a Modern Aesthetic of Existence
}

\author{
Nikolaos Tsiros \\ Professor of Panteion University of Social and Political Sciences \\ Department of Sociology \\ 136,Syggrou Ave. \\ Athens \\ Senior Advisor to the Legal Council of the Hellenic State
}

\begin{abstract}
Late Foucault completes his study about the phenomenon of power with the analysis of the so-called "Practices of Self" which define the moral formation of the subject. The concept of the "Practices of the Self" is related to the methods which affect the body, the soul, the thoughts and the behavior of the individuals so that they subsequently form themselves. Foucault discusses with the ancient Greek moral philosophy and describes a series of practices of living, through which the aesthetic experience of "living well" arises. In Xenophon's Oeconomicus an early ecosystem of the ancient Greek measure emerges, where starting from olko $=$ home the problem of the governing in relation to self and the closest others is posed. The self-control emerges as the condition for a financially self-sufficient home and by extension for a fair and happy town. The study attempts to answer the question to what extent the ecosystem of Oeconomicus can still be of use and applied in modern times which are characterized by radical individualisation and social disintegration. If, subsequently, the different socioeconomical structure of modernity in relation to the basically rural economy of antiquity renders unnecessary or not the association of these two levels.
\end{abstract}

\section{A methodoligal issue: Foucault's turn to subject - centred analysis of the power.}

We can notice in the French philosopher's Michel Foucault's work three methodoligal directions related to the study of the phenomenon of power : a) the archaeological method, b) the genealogical method and c) the subject-centred method of analysis through the connection of power with the moral questioning of self in the ancient world. The archaeological method studies the history of sciences through the way of the social structure of various phenomena so that the parts can be systematized in a context of rules, principles or values. Foucault in his work "The History of Madness" "l studies for example the pre-history of Psychiatry and reveals that since the $18^{\text {th }}$ century and then the phenomenon of madness is defined as mental disease due to a certain structure of thought, in which madness constructs itself in terms of social exclusion. Gradually, the archaeological method comes out of the rigid field of the interpretative understanding and demands, here and now, the emergence of every speech manifestation before it can even be a known object of the political power. Foucault in his work "The Words and the Things" claims that the newer forms of knowledge and science constitute a man-centred understanding of existence. The man did not even exist as a concept before or during the classical era since the thought remained captive inside the representation. Man became a problem in modernity when the language stopped existing in the limits of its representation, that is, when its representational function became a major problem.

The representing subject turns into an object in order to attain a clearer idea of itself. Foucault, in his most structuralistic work of this period "The Archaelogy of Knowledge" studies the procedures and the rules, through which the "formations" of discourse emerged and were constituted in the science domain. Specific political, economic and constitutional "regimes of constructing truth" dominated the production of knowledge and as a result, they were rendered in controlled and disciplinary practices of the modern power from the beginning. The fundamental acceptance of the archaeogical method is clearly depicted in this work :

The systems of thought and knowledge are regulated by rules beyond the ones of grammar and logic, that function beyond and beneath the individual consciousness in a specific historic time and place. The genetical error of the

\footnotetext{
${ }^{1}$ Michel Foucault (2004), The History of Madness, Iridanos, Athens.

${ }^{2}$ Michel Foucault (2008), The Words and the Things, An archaeology of the Sciences of Man, Gnosis, Athens.

${ }^{3}$ Michel Foucault (1987), The Archaeology of Knowledge, Exadas, Athens.
} 
archaelogical method is that it is impeded in the dialectical explanation of the causes that lead from the one way of thinking to the other.

Subsequently, it does not offer a persuasive tool for the explanation of the power claims which are established in modern thought. The empirical search of the power practices is absent and, furthermore, the interpretation of speech practices in their authoritative function ${ }^{4}$.

Foucault skips this difficulty with his turn to the genealogical method of work from the beginning of the 1970's decade. What is sought after now is the empirical analysis of the practices of power, in particular the truth claims that appear in the construction of its dominant speech. The connection of modern power with the practices of its domineering speech takes place through a constant attempt of historification of partial events without any reference to metaphysical principles and foundations. In his work, "Discipline and Punish" the analysis of the disciplinary power though the punitive system shapes a positive-productive concept of power : it penetrates the social body from an extreme edge as it pervades all social practices and relationships.

The first step to the understanding of the authoritative phenomenon as "power - knowledge" traversing all the thoughts, positions, activities and functions of the social body has been taken. Subsequently, Foucault worked on the concept of biopower in his work "The History of Sexuality" (volume $\left.1^{\text {st }}\right)^{6}$ and on the way the modern techniques of power are used as stereotypes for the total control of the human body and through which, for the unimpeded development of the capitalistic organization of the production. The appearance of biopower characterizes historically that crucial moment for the modernity during which the subject became, body and soul, an object of calculation by the modern political systems. Until now, Foucault refuses to interpret subjectively the concept of power and he is barely interested in who exercises it and how. He only sees chain reactions against power but also in this case, this relation power-resistance is tautological and so, the resistance is not set as a substantial issue in contrast to a form of "substance" of the power but only as a capacity of the governed until the moment when they are inevitably involved in the power game.

Thus, the power eliminates itself in its practices and its various abuses and compulsions. The question is if the course of social rationalization can be understood unilaterally through the genealogical method of analysis of the modern power relations or if it demands, furthermore, a necessity of emancipation and freedom which will allow the subject to seek the improved conditions of its individual and social survival.Foucault feels that id rationalization renders functionally equivalent to its power practices, then, any thought, over the construction of a moral subject insistently seeking the conditions of its emancipation, is automatically ruined.

Thus, in its late work and specifically in "The History of Sexuality" (volume 2 and 3) ${ }^{7}$, the philosopher attempts his third and last methodological turn. Starting from classical antiquity he described those self practices that recommend the criteria of an "aesthetics of existence". The "aesthetics of existence" refers to codes of conduct of the antiquity which form a fourfold subject area of its moral reflection : a) the moral problem of pleasures, b) the dietetics of the body and the pleasures, c) the marriage bond and d) the problem of relations among boys.

The new formulation of a genealogy of self-practices that will form a relation with oneself according to self-restraint, prudence and moderation on self-composure terms, dramatically changes the whole discussion so far.Foucault now focuses his attention on the subject that has to direct its course in such a way that it will free itself from its passions and endless use of pleasures. The subject which establishes a relation to oneself based on "domination - obedience" becomes morally good and so an "autocratic" structure of the subject during the practical use of its pleasures is mentioned. ${ }^{8}$ A deep, moral pluralism unfolds in Foucault's late work. The care of self presupposes the knowledge of self and the needed labour of a whole life for its attainment. The target is a subject able to govern itself relating the worse sides of itself and in continuation able to materialize the demand of the happy town in its relation to the others. The subject-centred turn of Foucault is subsequently combined with a demand of individual and collective euphoria.

\section{The paradigm of Xenophon's Oeconomicus : The ecosystem of ancient home as a model for the renewed interpretation of power by Foucault.}

\footnotetext{
${ }^{4}$ Tsiros Nikos (2017), Political legitimation and human rights in the work of JurgenHabermas, The turn of the modern social theory to the philosophy of law, Papazisis, Athens, pp.124-125.

${ }^{5}$ Michel Foucault (2008), Discipline and Punish, The Birth of Prison, Kedros, Athens.

${ }^{6}$ Michel Foucault (2011), History of Sexuality, The Will for knowledge (First Volume), Plethron, Athens.

${ }^{7}$ Michel Foucault (2013), The History of Sexuality, The Use of Pleasure (second volume) and History of Sexuality, The Care of the Self (third volume), Plethron, Athens.

${ }^{8}$ Michel Foucault (2013), The History of Sexuality, The Use of Pleasures (second volume), pp.90-91. 
I will present further on the way by which the "aesthetics of existence" in Foucault's work is connected with the idea of ecosystem and I will pose the question, if this idea can refer to modern ways of life. By ecosystem we mean a basic ecological unit consisting of the natural surroundings and the organisms that live in it.

An ecosystem has the ability to keep its balance as long as its auto-regulating mechanisms bring back the balance among the relations of the organisms that live in it, when it tends to be disrupted.In Foucault's case the ecosystem takes the shape of a radical politically active field where the self and the social surroundings form together a political sphere in which the surroundings are not only what exists externally but much more the place of a more or less anthropocentric and viable town. ${ }^{9}$ It was adequately mentioned, that the concept of "Care of self" is not solipsistic because it is based on attitudes, practices and actions primarily of relations. Indeed, the "Care of Self" presupposes a form of spirituality which is established through a totality of daily practice of exercises and meditation.

These personal practices are at the same time political since the whole issue is about the fulfillment of an educated citizen who, in his interaction with the others, will pose the moral-spiritual context of a collectively integrated and selfsufficient life. The political significance of a self-dominated subject does not stop at the individual choices over various aspects of daily life (diet, entertainment etc), but it inevitably refers to the social environment. It refers to a field of relations of power, an "ecopolis" in which people are related to other alive beings or inanimate things. ${ }^{10}$ This public sphere recognizes the forces and the flows among people and the rest of animate beings. From this point of view, the "Care of Self" is a supreme social practice, an accelerator of social relationships that connects the problem of the subject with the genealogy of governing, that is the ability of the autonomous subject for self-control and political domination.

In short, the subject-centred turn in Foucault's method transfers the problem of power in the citizen's daily life. Specific "self technologies" have a planning reference to a moralizing function that teaches the subject to comprise itself of identity terms.

The concept of governmental ability express in the ancient world a form of political knowledge which systematizes and regulates power relations primarily with the self itself. One learns to rationalize one's everyday living through those self-esteem and control techniques which will subsequently enable him to pose the question of domination on the collective level of the town under proportionally rational terms. The self becomes in this way a first -quality hybrid ecosystem which regulates in a purely self-contained, autonomous way its relationship with the others. The fulfillment, on terms of ecosystem, of the inner balance of the citizen with oneself is the necessary condition for the harmonious transfer to the broader ecosystem of the town. Various individuals can keep the ecosystem of their town balanced as much as they have primarily managed to control themselves and their home. The study of home as a total of rational practices that shape the art of governing is one of the most characteristic examples that reveals that the ability to govern others presupposes the ability to govern oneself. That is when self governed well as an ecosystem unit, then a broader ecosystem such as the one of the home or the town is also governed well.

Foucault devoted an extensive analysis to the Oeconomicus of the Athenian historian Xenophon in the third chapter of his work "The History of Sexuality" (Volume $2^{\text {nd }}$ " "The use of pleasures") ${ }^{11}$.Oeconomicus contains the most complete treatise of wedding life saved from classical Greece. ${ }^{12}$ Socrates and Kritovoulos, son of Krito, appear in the beginning of the dialogue to discuss about the concept of wealth which they identify with usefulness and well-being and not only with the possessions themselves, From the beginning of the text, the mutual agreement of the interlocutors that the economy is a science leads the discussion to the emergence of the rational practices through which the land owners of that time would manage the paternal inheritance with the aim of maintaining and developing it. Literally, economy is the name of a science, whereby people seem to be able to develop their homes. It should be mentioned that in classical Greece, oikos was not a synonyme of the family but it also included the fields and the possessions wherever they are even off the limits of the town : whatever one possesses belongs to oikos $=$ home. ${ }^{13}$ Aristotle already starts the conversation about politics distinguishing between the necessary abilities to run a house and to manage a town.

\footnotetext{
${ }^{9}$ Hroch Petra (2011), “Encountering the Ecopolis”. Foucault's EpimeleiaHeautou and Environmental Relations' in : Canadian Journal of Cultural Studies (special issue), p.2 (online).

${ }^{10}$ Hroch Petra (2011), as mentioned above, pp.6.

${ }^{11}$ Michel Foucault (2013), The History of Sexuality. The Use of Pleasures ( ${ }^{\text {nd }}$ Volume) see above pp.188-205.

${ }^{12}$ Xenophon (1997), Oeconomicus, Evalios, Athens.

${ }^{13}$ Xenophon, see above ,p.20.
} 
In other words, in antiquity, oikos is juxtaposed to town and the economy to politics. On ecosystem terms, oikos is based on hieriarquical structures of power in order to be managed whereas the town is based on the equality among free men. $^{14}$

Nevertheless, the management of home entails governing it and in this sense it does not differ from exercising power in the town. As Foucault points out, the common aim of domestic and political art is the governing of others.

In the words of Oeconomicus it is a divine gift when one can govern people who want to obey him because he is educated and he is good by nature. ${ }^{15}$ Thus, from the $7^{\text {th }}$ chapter and on, Socrates announces to Kritovoulos the discussion he once had with the Athenian Ishomahos just before he got married and he described at length to the philosopher the nature and the conditions of his family life. Xenophon examines at length the family relationship in the context of home, as one part of the responsibility that the man has to govern so that he enables his wife to be partner is his affairs. Foucault notices the marriage asymmetry since the man decides for himself and the girl's family decide for her. ${ }^{16}$ The target is the mutual activities of both partners to be organized in such a way so that the production on the man's side is secured and on the woman's side the maintenance and arrangement of the produced goods.

Xenophon's ecosystem is, subsequently, agricultural relating its economic basis. It corresponds accurately to the unpredictable at times weather and natural environment, against which the detailed distribution of marriage roles is juxtaposed as a condition of home self-sufficiency and affluence.

In Oeconomicus the production, the seasonal pace, the waiting of the crops and the yield in its proper time, in one word all the work which is done in the open air, are examined. Since both the open-air work as well as the work in the house demand care, Xenophon calls on the virtue of self-restraint as common virtue of both sexes. Though, in Ishomaho'scase, that is of the male side of marriage, self-restraint does not only mean to be able to control one's passions. Moreover, it is manifested as the guiding pedagogical condition for his wife's self-restraint : self-restraint refers to the make up of the wife, which is something she does not need to remain her husband's object of desire. The real beauty of the woman lies, according to Ishomahos in the responsible governing of her house. Using her powerful role in moderation, the woman who does responsibly her domestic chores will not remain idle like a slave or passive as a vain one. The prevailing position of woman in her house makes her stand out in relation to the female slaves and earn her beauty in an energetic way by standing and being involved in any domestic work. ${ }^{17}$ In this way, the prevailing role of wife is secured and she cannot fall off her position and be replaced by another woman in her husband's side ${ }^{18}$.

According to Foucault, the threat in the marriage does not come from husband's accidental pleasures but from the opposing pursuits that the wife may have with the other women in the house relating prevalence.

Thus, the "male" art of governing the house, the wife, the servants and the paternal inheritance id founded in a bilaterally defined relation : self-restraint becomes the wisdom index of the husband whereas the wife will keep her legal rights by acting her best at home.

According to the above mentioned, the husband's self-restraint does not only express a virtue but it also demonstrates a practice of governing himself as well as his wife whom he must keep and respect, since she will be the obedient lady of the house. Ishomaho's house ecosystem reflects rationalized historic, practices of a world characterized by agricultural economic structure and by patriarchal vertical power relations.

The demand for the male's self-restraint is posed as the presupposition for the economic management of the house on self-sufficiency terms. A self-sufficient house covers the necessary material conditions so that the landowner - citizen can be free and equivalent with his fellow co-citizens in the public affairs of his town. The connection between economic and political element is more than obvious and constantly revealed both in the house as well as in the town. Inside the house, economy as a science is materialised through certain governing practices of the self and of the others, subsequently it is materialised through an early political exercise of "male" power. So, the free and equal involvement of the citizen in the public affairs of the town will depend on the previous, satisfactory organization of the economy inside his house, that is on the abilities he showed on governing himself and the ones directly dependent on him.

\footnotetext{
${ }^{14}$ See Mitropoulos Angela (2012), Contract and Contagion. From Biopolitics to Oikonomia, Minor Compositions Press (online), p.72.

${ }^{15}$ Xenophon, see above, p. 257.

${ }^{16}$ Michel Foucault (2013), see above, p.193.

${ }^{17}$ Michel Foucault (2013), see above, p.201.

${ }^{18}$ As mentioned above, p.203. 
Thus, home, as a self-sufficient biotic ecosystem, becomes the decisive factor for the construction of the happiness seeking town. Disturbed homes due to the economic insufficiency and the inner conflicts of its members put the immediate risk of a general rebellion and social upheaval conducive to the fall of the moral foundations of the town.

\section{From antiquity to modernity : Limits and abilities of application of the agricultural ecosystem under conditions of neo liberal domination.}

There are a lot of scholars dealing with Foucault's work in modern scientific speech, who try to apply the rules of bio power and governmentality to analyses concerned with the regulation of social interactions with the natural world. ${ }^{19}$ Thus, the concept of ecological or environmental governmentality started shaping since the mid 1990s by some scholars who used Foucault's ideas for the development of studies, which investigate the problems of climatic change on a national and international level. The studies for the application of governing terms in order to face the dramatic climatic change in the planet gradually shifted the discussion towards the political governing of the planet. The late political ecology understands that the rapid consumerism and the ongoing commercialization in the relation of the individual with his environment demand the reconsideration of Foucault's disciplinary power. Henceforth, govern mentality is generalized as "environmental discipline" in the broader sense of a power which ought to patrol the suitability of all the biological organisms and of the health of their natural environment. Since the environment is given prominence for the possible normalization of the individual behaviour targeting the assurance of all the biodiversity of life, then models of economic and political management on a local, state and interplanetary level must be sought.

It is about models that will not deplete the scarcity of natural resources under conditions of neoliberal societies, where power appears without hierarchy and decentralized and therefore their members will have to play a drastic role in their self-government.This is supposed to happen in the context of neo liberal governing. The individuals will rely on the knowledge which allows them to autoregulate and auto adjust their relation with their natural environment in the context of a power which is based on the free market mechanisms and on the elimination of the acts of the state.

Foucault himself finds the neo liberal rationalization interesting because it focused its interest on the subject as subject and not as an object of the disciplinary power. ${ }^{20}$ The "new" in neoliberalism lies in the attempt of connecting the individual with oneself as an entrepreneur. Homo economicus is read as the self which produces a new chapter, which consequently becomes the explanatory principle for the analysis of human behaviour in the language of capital, investments and entrepreneurship. The most crucial characteristic $\mathrm{f}$ neo liberalism is that man and the human capital are converted into an unbroken whole. ${ }^{21}$ This of course has consequences regarding the bestowal of meaning of the external nature on "ecosystem" terms. The nature which once meant a separate and confined space from the social body now becomes more and more "environment" of the capitalist system. The new interpretation of the governmental policy as "environmental" attempts in essence to redirect the limits between "nature" and "society" with the aim of a dynamic increase and not of a restriction of these limits. The economic exploitation demands, in Foucault's terms, a preceding political investment $\mathrm{n}$ the body and this happens with more or less reflective ways of exercising power, that is what the French philosopher summarized as "technological" ways of exercising it. ${ }^{22}$

Nevertheless, the question remains open if the paradigm of the agricultural ancient Greek ecosystem of a patriarchally structured home can be used as interpretative tool of analysis in the modern massive democracies of metamodernity. A series of crucial social differentiations give a negative answer in the beginning: a) modern societies are not primarily agricultural but radically urbanized, impersonal and fragmented, b) these societies do not belong to the patriarchal model of the distant historical ast, since woman's involvement in the political and economic life has been assured, c) the nepotism system of social organization is presented weaker and weaker as a result of the radical individualization and of the domination of massive democratic equalizing demands and d) the concept of "ecosystem" is liquidized more and more by the systematic invasion of the human factor in his natural environment.

\footnotetext{
${ }^{19}$ See for example, MaletteSebastien (2009), “Foucault for the next century : eco governmentality”, in Binkey, Capetillo (eds.), A Foucault for the $21^{\text {st }}$ century : Govern mentality, Biopolitics and Discipline in the Next Millennium, Cambridge Scholars Publishing : London, p.p221-237, Darier Eric (1999), “Foucault and the Environment : An Introduction”, in Darier (ed,), Discourses of the Environment, Blackwell Publishers : Mass, pp.1-34

${ }^{20}$ Compare Dilts Andrew (2011), "From Entrepreneur of the Self”" to "Care of the Self" :Neo-Liberal Govern mentality and Foucault's Ethics", in Foucault Studies, No12, pp.143-144.

${ }^{21}$ Dilts, as above, p.136.

${ }^{22}$ See Lehmke Thomas (2000), “Foucault, Governmentality and Critique”, in Rethinking Marxism, Vol.14, Num.3, p.5 (online).
} 
The ongoing "socialization" of nature by the man-invader is an unprecedented historical fact which comes as a result of industrialization and ubranisation of the last two centuries. As it is understood, the philosophical ancient Greek speech could not in fact face the dangers that the modern social contract breeds. From this point of view, the deciphering of modern governmental power poses a question about its purpose, beyond a narrow ideological rhetoric which is the political plan that will lead to a better social reality than the already existing.

Here lies a possible, positive echo of Foucault's meeting with the Oeconomicos of Xenophon : Regardless of the different, economic and social structures of the ancient Greek world with our modern one, this text describes a way of exercising power, which ontologically relies on the ethnics of self's care and of the mutual wedding moderation. The purpose of ruling in home is the economic sufficiency as the materialistic basis for the foundation of a happy town. In Foucault's neoliberal account the ways are revealed by which the subjects are made by the modern power relations.

The practices of freedom are absent, though in this neoliberal scenario, which as part of the human work will constitute the ethics ahead of the identity of the subject. ${ }^{23}$ Foucault reminds us that the ancient Greek thought made possible a certain historic knowledge of the society: it is about the possibility of exercising power on self-awareness conditions leading to freedom and equality. Thus, it is up to the descendants of this thought to historisize the demands for freedom and equality in modern occasions. That means that late Foucault never brought about a breach in the relation of the power genealogy with a subject theory. To the contrary though, the way that the ancient Greek thought sets as problems moral issues that have to do with self-improvement and self-restraint, is related to a long philosophical tradition which tries not to lose its ontological background.

A self which seeks its liberation through his self-commitment is the model of man in Xenophon's Oeconomicous. To the contrary, a self seeking its freedom through his liberated individualization becomes the pattern of the lonely subject in the times of modernity.

\footnotetext{
${ }^{23}$ Dilts, see above, pp.144-145.
} 